\title{
EFEKTIVITAS MODEL PEMBELAJARAN THINK-PAIR-SHARE (TPS) TERHADAP KEMAMPUAN KOMUNIKASI MATEMATIS SISWA
}

\author{
Illiyyin Darojatil ‘Ula ${ }^{1}$, Murtono ${ }^{2}$, dan Himmatul Ulya ${ }^{3}$ \\ ${ }^{1,2}$ Prodi Pendidikan Guru Sekolah Dasar, Universitas Muria Kudus \\ ${ }^{3}$ Prodi Pendidikan Matematika, Universitas Muria Kudus
}

\section{Info Artikel \\ Sejarah Artikel: Diterima 24 Feb 2018 \\ Direvisi 20 Mar 2018 \\ Disetujui 20 Apr 2018}

Keywords: Effectiveness, Mathematical Communication Ability Think Pair Share,

\section{Paper type:}

Research paper

\begin{abstract}
The objectives of this research are (1) to describe the average difference of mathematical communication ability of grade V elementary school students, and (2) to find the Think-Pair-Share (TPS) learning model to meet the qualification of the effectiveness of mathematical communication ability of grade V students of Elementary School. Research method used is experimental research with posttest Only Control Group Design Design research. The population are the students of grade VSDN 1 and 2 Pendosawalan academic year 2016/2017. The sample used is the students of class V SDN 1 Pendosawalan as the control class and the students of grade V B SDN 2 Pendosawalan as the experimental class. The sampling technique in this research is simple random sampling technique. Data collection using test. Data analysis include initial data analysis, data normality test, data homogeneity test, and equality test average, and final data analysis is data normality test, data homogeneity test, learning mastery test, and test of average difference from sample who have been treated. The results of the mean difference test indicate that between the experimental class and control class students have a significantly different mean of mathematical communication ability. In the results of individual learning completeness test concluded that students who get the TPS learning model got the average test of the mathematical communication skills $>75$, while the classical completeness test concluded that the average student who complete the KKM amounted to more than $75 \%$.
\end{abstract}

\begin{abstract}
Abstrak
Tujuan penelitian ini adalah (1) mendiskripsikan perbedaan rata-rata kemampuan komunikasi matematis siswa kelas V Sekolah Dasar, dan (2) menemukan model pembelajaran Think-Pair-Share (TPS) dapat memenuhi kualifikasi keefektifan kemampuan komunikasi matematis siswa kelas V Sekolah Dasar. Metode penelitian yang digunakan adalah penelitian eksperimen dengan rancangan penelitian Posttest Only Control Group Design. Populasi dalam penelitian ini adalah siswa kelas V SDN 1 dan 2 Pendosawalan tahun ajaran 2016/2017. Sampel yang digunakan yaitu siswa kelas V SDN 1 Pendosawalan sebagai kelas kontrol dan siswa kelas V B SDN 2 Pendosawalan sebagai kelas eksperimen. Teknik pengambilan sampel dalam penelitian ini adalah teknik simple random sampling. Pengumpulan data menggunakan tes. Analisis data meliputi analisis data awal yaitu uji normalitas data, uji homogenitas data, dan uji kesamaan rata-rata, dan analisis data akhir yaitu uji normalitas data, uji homogenitas data, uji ketuntasan belajar, dan uji perbedaan rata-rata dari sampel yang telah diberi perlakuan. Hasil uji perbedaan rata-rata menunjukkan bahwa antara siswa kelas eksperimen dan siswa kelas kontrol memiliki rata-rata kemampuan komunikasi matematis yang berbeda secara signifikan. Pada hasil uji ketuntasan belajar individual disimpulkan bahwa siswa yang memperoleh model pembelajaran TPS mendapat nilai rata-rata tes kemampuan komunikasi matematis $>75$, sedangkan uji ketuntasan klasikal disimpulkan bahwa rata-rata siswa yang tuntas KKM berjumlah lebih dari $75 \%$.
\end{abstract}

\footnotetext{
$\triangle$ Alamat korespondensi:

Program Studi Pendidikan Matematika, Universitas Muria Kudus

Kampus UMK Gondangmanis, Bae Kudus Gd. L lantai 1 Ruang 2 PO BOX 53 Kudus

Tlp. (0291) 438229 Fax. (0291) 437198

E-mail: liyindarla3@gmail.com
} 


\section{PENDAHULUAN}

Pendidikan merupakan faktor kunci dalam peningkatan sumber daya manusia. Sumber daya manusia yang berkualitas dapat mendorong perkembangan teknologi di masa mendatang. Teknologi yang berkembang dapat mengantarkan manusia untuk semakin memperbaiki tatanan kehidupannya. Matematika merupakan salah satu bagian dari pendidikan tersebut.

Matematika sebagai mata pelajaran sering dianggap sulit oleh sebagian siswa. Konsep dasar pada materi matematika seringkali tidak tersampaikan dengan baik kepada siswa. Faktor yang menjadi sebab masalah tersebut diantaranya adalah guru sebagai penyalur ilmu pengetahuan hanya menggunakan model pembelajaran ekspositori dengan metode ceramah, dan tidak memiliki media pembelajaran yang mendukung proses pembelajaran. Peters dalam Sudjana (2011) mengemukakan ada tiga tugas dan tanggung jawab guru, yakni: (a) guru sebagai pengajar; (b) guru sebagai pembimbing; (c) dan guru sebagai administrator kelas. Guru sebagai pengajar dan pembimbing telah menekankan bahwa pemahaman siswa terhadap materi pelajaran termasuk matematika adalah tanggung jawab guru.

Komunikasi matematis termasuk dalam tujuan pembelajaran matematika di sekolah yang terdapat pada Kurikulum Tingkat Satuan Pendidikan (KTSP). Tujuan pelajaran matematika tersebut diantaranya mengkomunikasikan gagasan dengan simbol, tabel, diagram, atau media lain untuk memperjelas keadaan atau masalah (Depdiknas:2006). Latifah (2011:3) mengemukakan kemampuan komunikasi matematis diartikan sebagai kemampuan merefleksikan suatu gambar ke dalam ide-ide matematika, menyatakan permasalahan matematika dengan menggunakan simbol-simbol dan memberikan penjelasan dengan bahasa sendiri dengan penulisannya secara sistematik. Menurut Susanto (2013:213) komunikasi matematis dapat diartikan sebagai suatu peristiwa dialog atau saling hubungan yang terjadi di lingkungan kelas, dimana terjadi pengalihan pesan, dan pesan yang dialihkan berisikan tentang materi matematika yang dipelajari siswa, misalnya berupa konsep, rumus, atau strategi penyelesaian suatu masalah. Indikator kemampuan komunikasi matematis yang dikemukakan Lestari dan Yudhanegara (2015:83) ada tujuh, yaitu: (1) menghubungkan benda nyata, gambar, dan diagram ke dalam ide matematika; (2) menjelaskan ide, situasi, dan relasi matematika secara lisan atau tulisan, dengan benda nyata, gambar, grafik, dan aljabar;
(3) menyatakan peristiwa sehari-hari dalam bahasa matematika; (4) mendengarkan, diskusi, dan menulis tentang matematika; (5) membaca dengan pemahaman suatu presentasi matematika tertulis; (6) menyusun pertanyaan matematika yang relevan dengan situasi masalah; (7) membuat konjektur, menyusun argunen, merumuskan definisi dan generalisasi. Ulya dan Rahayu (2017) menyimpulkan bahwa komunikasi matematis merupakan cara berbagi ide dan memperjelas pemahaman tentang matematika.

Praktik yang ditemukan dilapangan memperlihatkan kualitas pembelajaran matematika di Indonesia masih banyak kekurangan. Berdasarkan Naskah Kebijakan Kurikulum Mata Pelajaran Matematika oleh Depdiknas (2007:12) diketahui bahwa dari data hasil identifikasi berdasarkan aspek pelaksanaan pembelajaran SD/MI ditemukan permasalahan metode pembelajaran di kelas yang kurang bervariasi, guru cenderung selalu menggunakan model pembelajaran ekspositori dengan metode ceramah dan tanya jawab.

Pembelajaran matematika yang diajarkan guru di SDN 1 dan 2 Pendosawalan masih menggunakan model pembelajaran ekspositori. Hasil observasi menunjukkan bahwa guru cenderung lebih aktif dalam menyampaikan materi kepada siswa. Siswa terlihat diam dan kurang aktif selama pembelajaran berlangsung. Interaksi hanya berlangsung satu arah, yaitu dari guru ke siswa. Siswa cenderung sulit untuk menyampaikan pendapat atau pertanyaan apabila ada bagian dari materi yang belum dimengerti oleh siswa, termasuk materi pada mata pelajaran matematika. Penggunaan media juga masih belum maksimal.

Upaya yang dapat dilakukan agar siswa mampu mengkomunikasikan ide dan gagasannya, salah satunya adalah dengan menerapkan model pembelajaran Think-PairShare (TPS). Menurut Trianto (2011:61) model think-pair-share (TPS) atau berpikirberpasangan-berbagi merupakan jenis pembelajaran kooperatif yang dirancang untuk mempengaruhi pola interaksi siswa. Suprijono (2012:91) mengungkapkan terdapat tiga tahap atau langkah-langkah inti dari model pembelajaran TPS, yaitu tahap Thinking, Pairing, dan Sharing. (1) tahap thinking, merupakan pembelajaran yang diawali dengan pertanyaan yang diberikan oleh guru tentang pelajaran yang sedang diajarkan untuk dipikirkan oleh siswa; (2) tahap pairing, yaitu siswa berpasang-pasangan untuk mendiskusikan pertanyaan yang tadi mereka pikirkan; (3) tahap sharing, yaitu tahap memaparkan hasil diskusi 
pasangan-pasangan di depan kelas. TPS memiliki keunggulan dalam praktiknya, diantaranya: (1) memungkinkan siswa untuk bekerja sendiri dan bekerjasama dengan orang lain; (2) mengoptimalkan partisipasi siswa; (3) memberi kesempatan pada siswa untuk menunjukkan partisipasi mereka kepada orang lain (Huda, 2014:206).

Penggunaan model pembelajaran ThinkPair-Share (TPS) pada penelitian ini untuk menguji keefektifan terhadap komunikasi matematis telah didukung dengan penelitian sebelumnya yang memiliki kesamaan latar belakang. Penelitian yang dilakukan oleh Arifin, Kartono, dan Sutarto (2014) menunjukkan bahwa kemampuan komunikasi matematis siswa kelas eksperimen lebih baik daripada kemampuan komunikasi matematis siswa kelas kontrol. Penelitian yang sama juga dilakukan oleh Husna, Ikhsan, dan Fatimah (2013) yang menunjukkan bahwa peningkatan kemampuan komunikasi matematis siswa dengan menggunakan pembelajaran kooperatif Think-Pair-Share secara signifikan lebih baik daripada siswa yang memperoleh pembelajaran konvensional bila ditinjau secara keseluruhan siswa.

Model pembelajaran Think Pair Share (TPS) merupakan model pembelajaran yang menerapkan metode berpikir-berpasanganberbagi, sehingga siswa dapat mendiskusikan kemudian menyampaikan atau mengkomunikasikan hasil kerja kelompoknya pada kelompok lain. Komunikasi matematispun dapat terasah melalui model pembelajaran TPS.

Penelitian ini bertujuan

mendiskripsikan perbedaan rata-rata kemampuan komunikasi matematis siswa kelas V Sekolah Dasar, dan (2) menemukan model pembelajaran Think-Pair-Share (TPS) dapat memenuhi kualifikasi keefektifan kemampuan komunikasi matematis siswa kelas V Sekolah Dasar.

\section{METODE PENELITIAN}

Jenis penelitian yang digunakan dalam penelitian ini adalah jenis penelitian kuantitatif yaitu eksperimen dengan desain penelitian Posttest Only Control Group Design, yang dapat digambarkan pada Tabel 1 sebagai berikut.

Tabel 1. Contoh tabel yang sesuai dengan kolom

\begin{tabular}{lcc}
\hline Kelompok & Perlakuan & Pengaruh \\
\hline R (Kelas Eksperimen) & $\mathrm{X}$ & $O_{1}$ \\
R (Kelas Kontrol) & & $O_{2}$ \\
\hline
\end{tabular}

(Sugiyono, 2015:114)

Keterangan:

$\mathrm{R}$ : Kelompok dipilih secara random

$\mathrm{X}$ : Pembelajaran TPS

$O_{1}:$ Postest di kelas eksperimen

$\mathrm{O}_{2}$ : Postest di kelas kontrol
Bentuk desain penelitian posttest only control group design merupakan desain penelitian yang memilih dua kelompok secara random (R), yaitu kelas eksperimen dan kelas kontrol. Kelompok yang diberi perlakuan (X) disebut kelompok eksperimen. Kelompok yang tidak diberi perlakuan disebut kelompok kontrol. Pengaruh adanya perlakuan (treatment) adalah $O_{1}$ dan $O_{2}$.

Penelitian ini dilakukan di SDN 1 dan 2 Pendosawalan. Populasi dalam penelitian ini adalah siswa kelas V SDN 1 dan 2 Pendosawalan tahun ajaran 2016/2017 dengan total populasi berjumlah 84 siswa. Sampel yang digunakan adalah kelas V SDN 1 Pendosawalan sebagai kelas kontrol dan kelas V B SDN 2 Pendosawalan sebagai kelas eksperimen. Teknik pengambilan sampel dalam penelitian ini adalah teknik simple random sampling, yaitu pengambilan anggota sampel dari populasi dilakukan secara acak tanpa memperhatikan strata yang ada dalam populasi itu (Sugiyono, 2012:120).

Teknik pengumpulan data dalam penelitian ini menggunakan tes. Alat pengumpul data yang digunakan adalah soal tes kemampuan komunikasi matematis. Pembuatan soal tes disesuaikan dengan indikator kemampuan komunikasi matematis dan materi mengidentifikasi sifat-sifat bangun ruang.

Penelitian dilakukan melalui tiga tahap, yaitu 1) tahap perencanaan; 2) tahap pelaksanaan; dan 3) tahap analisis data.

Kegiatan yang dilakukan selama tahap perencanaan antara lain: 1) melakukan dokumentasi hasil ulangan harian semester 1 materi volume kubus dan balok; 2) melakukan observasi pada kinerja guru dan aktivitas siswa ketika pembelajaran materi mengidentifikasi sifat-sifat bangun datar sedang berlangsung; 3) menganalisis data awal yaitu data nilai ulangan harian matematika semester 1 siswa kelas $\mathrm{V}$ SDN 1 dan 2 Pendosawalan materi volume kubus dan balok; 4) menyusun desain penelitian; 5) membuat instrumen penelitian berupa kisi-kisi tes, soal tes kemampuan komunikasi matematis (posttest), kunci jawaban dan penskoran, silabus dan RPP untuk kelas kontrol dan kelas eksperimen, membuat lembar observasi; 6) melakukan validasi ahli pada soal tes kemampuan komunikasi matematis; 7) mengadakan uji coba soal tes kemampuan komunikasi matematis; 8) menganalisis data hasil uji coba tes; 9) merevisi instrumen penelitian berdasarkan hasil uji coba tes; 10) menentukan waktu penelitian. 
Kegiatan yang dilakukan dalam tahap ini antara lain: 1) Kelas eksperimen: a) melakukan pembelajaran dengan model pembelajaran ThinkPair-Share (TPS); b) memberikan posttes berupa soal tes kemampuan komunikasi matematis materi mengidentifikasi sifat-sifat bangun ruang; c) melakukan observasi oleh observer; d) menganalisis hasil observasi. 2) Kelas kontrol: a) melakukan pembelajaran dengan model pembelajaran ekspositori; b) memberikan posttes berupa soal tes kemampuan komunikasi matematis materi mengidentifikasi sifat-sifat bangun ruang; c) melakukan observasi oleh observer; d) menganalisis hasil observasi.

Kegiatan yang dilakukan dalam tahap ini anatar lain: 1) mengumpulkan hasil penelitian kuantitatif; 2) melakukan analisis data kuantitatif hasil posttes dari soal tes kemampuan komunikasi matematis materi mengidentifikasi sifat-sifat bangun ruang; 3) menyusun hasil penelitian.

Teknik analisis data dalam penelitian ini meliputi analisis data awal dan analisis data akhir. Analisis data awal dilakukan sebelum penelitian dilakukan. Data awal dalam penelitian ini adalah nilai ulangan harian matematika semester 1 siswa kelas V SDN 1 dan 2 Pendosawalan materi volume kubus dan balok. Setelah data didapatkan, dilakukan analisis data awal berupa uji normalitas data, uji homogenitas data, dan uji kesamaan rata-rata. Analisis data akhir dilakukan setelah mendapatkan nilai hasil posttest pada tes kemampuan komunikasi matematis. Analisis data akhir yang dilakukan yaitu uji normalitas data, uji homogenitas data, uji ketuntasan belajar, dan uji perbedaan rata-rata dari sampel yang telah diberi perlakuan.

\section{HASIL DAN PEMBAHASAN}

Penelitian ini dilakukan di kelas kontrol dan kelas eksperimen dengan tiga kali pertemuan pada masing-masing kelas. Teknik pengambilan sampel dalam penelitian ini adalah teknik simple random sampling dan didapatkan kelas V SDN 1 Pendosawalan sebagai kelas kontrol (KK) dan kelas V B SDN 2 Pendosawalan sebagai kelas eksperimen (KE).

Data yang digunakan dalam penelitian ada dua, yaitu data awal dan data akhir. Data awal adalah nilai ulangan harian siswa pada semester 1 kemudian dilakukan pengujian berupa analisis data awal. Data akhir merupakan hasil yang diperoleh dari nilai tes kemampuan komunikasi matematis juga dilakukan pengujian berupa analisis data akhir.

Pada data awal, sebelum penelitian dilakukan maka data perlu diuji normalitas, uji homogenitas, dan uji persamaan rata-rata. Hasil uji normalitas data awal dapat dilihat pada Tabel 2.

Tabel 2. Hasil Uji Normalitas Data Awal

\begin{tabular}{|c|c|c|c|c|c|}
\hline No & Kelas & $\mathrm{N}$ & $X_{\text {Litung }}^{z}$ & $X_{\text {fisbsI }}^{2}$ & Keterangan \\
\hline 1. & KK & 36 & 7.585 & 7.81 & Normal \\
\hline 2. & $\mathrm{KE}$ & 24 & 3.214 & 7.81 & Normal \\
\hline & \multicolumn{4}{|c|}{ Berdasarkan perhitungan uji } & norm \\
\hline data & awa & & las & kontrol & diperole \\
\hline anters & $=$ & 585 & Pada & kelas & eksperi \\
\hline
\end{tabular}

didapatkan $X_{\text {tikury }}^{z}=3,214$. Karena taraf signifikansi $(\alpha)$ adalah 5\% maka ${ }_{X_{\mathrm{taksI}}^{z}}=7,81, \mathrm{dk}$ $=\mathrm{k}-3=6-3=3$. Hasil analisis data tersebut, terlihat bahwa pada kelas kontrol dan kelas eksperimen diperoleh ${ }_{X_{\text {titung }}^{z}}<X_{X_{\text {tabsI }}^{z}}$ maka ${ }_{H_{0}}$ diterima. Hal ini berarti data awal dalam penelitian ini berasal dari populasi yang berdistribusi normal.

Hasil uji homogenitas juga dapat dirangkum pada Tabel 3 berikut.

Tabel 3. Hasil Uji Normalitas Data Awal

\begin{tabular}{cccccc}
\hline No & Kelas & $\mathrm{N}$ & $X_{\text {thins }}^{z}$ & $X_{\text {tabsel }}^{z}$ & Keterangan \\
\hline 1. & KK & 36 & 7.585 & 7.81 & Normal \\
\hline 2. & KE & 24 & 3.214 & 7.81 & Normal \\
\hline
\end{tabular}

Berdasarkan perhitungan uji homogenitas data awal kelas eksperimen dan kelas kontrol diperoleh ${ }_{X_{\text {tikung }}^{z}}=0,591$ dan $X_{\text {tabs: }}^{z}=3,84$ dengan $\alpha=5 \%, \mathrm{dk}=\mathrm{k}-1=2-1=1$. Berdasarkan hasil analisis data tersebut, dapat terlihat bahwa ${ }_{X_{\text {titurng }}^{z}}$ ${ }_{X_{t=\mathrm{bs} P}^{z}}$ maka ${ }_{H_{0}}$ diterima. Hal ini berarti data kelas eksperimen dan kelas kontrol memiliki varians yang homogen.

Uji kesamaan rata-rata bertujuan mengetahui rata-rata kemampuan siswa dari dua kelas yang berbeda. Hasil uji dari kedua kelas tersebut kemudian dilihat, apakah kedua kelas memiliki rata-rata kemampuan siswa yang sama atau tidak. Pengujian ini menggunakan teknik independent samples t test dengan rumus Fisher. Hasil uji kesamaan rata-rata dapat dirangkum pada Tabel 4 berikut.

Tabel 4. Hasil Uji Kesamaan Rata-rata Data

\begin{tabular}{ccccc}
\multicolumn{5}{c}{ Awal } \\
\hline Kelas & $\mathrm{N}$ & $\mathrm{t}_{\text {hitung }}$ & $\mathrm{t}_{\text {tabel }}$ & Keterangan \\
\hline $\mathrm{KK}$ & 36 & 0,22867 & 2,07 & $\begin{array}{c}\text { Rata-rata } \\
\text { kemampuan awal } \\
\text { sama }\end{array}$ \\
\hline
\end{tabular}

Hasil perhitungan uji kesamaan rata-rata menunjukkan bahwa $\mathrm{t}_{\text {hitung }}=0,22867$ dan $\mathrm{t}_{\text {tabel }}=$ 2,07 dengan $\alpha=5 \%: 2=2,5 \%$, df $=n-2=24-2$ $=22$. Berdasarkan hasil analisis data tersebut, dapat terlihat bahwa $t_{\text {hitung }}<\mathrm{t}_{\text {tabel }}$ maka ${ }_{H_{0}}$ diterima. Hal ini berarti data kelas eksperimen 
dan kelas kontrol memiliki rata-rata kemampuan yang sama.

Data akhir pada penelitian ini merupakan nilai hasil tes kemampuan komunikasi matematis siswa kelas $\mathrm{V}$ pada materi mengidentifikasi sifatsifat bangun ruang. Data akhir diperoleh melalui tes kemampuan komunikasi matematis di kelas eksperimen dan kelas kontrol. Kelas eksperimen merupakan kelas yang diberi perlakuan model pembelajaran Think-Pair-Share (TPS), sedangkan kelas kontrol merupakan kelas yang tidak diberi perlakuan, menggunakan model pembelajaran ekspositori. Setelah penelitian, pada data akhir dilakukan uji normalitas, uji homogenitas, perbedaan rata-rata, dan uji ketuntasan belajar.

Hasil uji normalitas data akhir dirangkum dalam Tabel 5 berikut.

Tabel 5. Hasil Uji Normalitas Data Akhir

\begin{tabular}{|c|c|c|c|c|c|}
\hline No. & Kelas & $\bar{N}$ & $\chi_{\text {hitung }}^{2}$ & $\chi_{\text {tabel }}^{2}$ & Keterangan \\
\hline 1. & KK & 36 & 7.80 & 7.81 & Normal \\
\hline 2. & $\mathrm{KE}$ & 24 & 2.94 & 7.81 & Normal \\
\hline
\end{tabular}

Berdasarkan perhitungan uji normalitas

Pada kelas eksperimen didapatkan $\chi^{2}{ }^{2}=2,94$

Karena taraf signifikansi $(\alpha)$ adalah $5 \%$ maka $\chi_{\text {tabel }}^{2}=7,81, \mathrm{dk}=\mathrm{k}-3=6-3=3$. Hasil analisis data tersebut, terlihat bahwa $\chi_{\text {hitung }}^{2}<\chi_{\text {tabel }}^{2}$ maka $\mathrm{H}_{0}$ diterima. Hal ini berarti data akhir dalam penelitian ini berasal dari populasi yang berdistribusi normal.

Hasil uji homogenitas data akhir dapat dilihat pada Tabel 6 berikut.

Tabel 6. Hasil Uji Homogenitas Data Akhir

\begin{tabular}{ccccc}
\hline Kelas & $\mathrm{N}$ & $\chi_{\text {hitung }}^{2}$ & $\chi_{\text {tabel }}^{2}$ & Keterangan \\
\hline $\mathrm{KK}$ & 36 & \multirow{2}{*}{0.019158} & 3.84 & Homogen \\
$\mathrm{KE}$ & 24 & & & \\
\hline
\end{tabular}

Berdasarkan perhitungan uji homogenitas data akhir yaitu data hasil tes kemampuan komunikasi matematis di kelas eksperimen dan kelas kontrol diperoleh $\chi_{\text {hitung }}^{2}=0.019158$ dan $\chi_{\text {tabel }}^{2}=3,84$. Taraf signifikansi yang diambil adalah $5 \%(\alpha=5 \%), \mathrm{dk}=\mathrm{k}-1=2-1=1$. Hasil analisis data tersebut terlihat bahwa $\chi_{\text {hitung }}^{2}<$ $\chi_{\text {tabel }}^{2}$ maka $\mathrm{H}_{0}$ diterima. Hal ini berarti data kelas eksperimen dan kelas kontrol memiliki varians yang homogen.

Uji perbedaan rata-rata digunakan untuk mengetahui apakah terdapat perbedaan rata-rata yang signifikan dari data kelas eksperimen dan kelas kontrol. Pengujian menggunakan uji independent sample $t$ test seperti pada uji kesamaan rata-rata pada analisis data awal. Hasil uji perbedaan rata-rata dapat dilihat pada Tabel 7 berikut.

Tabel 7. Hasil Uji Perbedaan Rata-rata

\begin{tabular}{ccccc}
\hline Kelas & $\mathrm{N}$ & $\mathrm{t}_{\text {hitung }}$ & $\mathrm{t}_{\text {tabel }}$ & Keterangan \\
\hline $\mathrm{KK}$ & 36 & 2.836 & 2,07 & \multirow{2}{*}{$\mathrm{H}_{0}$ ditolak } \\
$\mathrm{KE}$ & 24 & & & \\
\hline
\end{tabular}

Hasil perhitungan uji perbedaan rata-rata menunjukkan bahwa $t_{\text {hitung }}=2.836$ dan $t_{\text {tabel }}=$ 2,07 dengan $\alpha=5 \%: 2=2,5 \%$, df $=n-2=24-2$ $=22$. Berdasarkan hasil analisis data tersebut, dapat terlihat bahwa $t_{\text {hitung }}>t_{\text {tabel }}$ maka $\mathrm{H}_{0}$ ditolak. Hal ini berarti data antara kelas eksperimen dan kelas kontrol memiliki rata-rata kemampuan komunikasi matematis yang berbeda secara signifikan. Simpulan yang dapat diambil, terlihat bahwa terdapat perbedaan rata-rata kemampuan komunikasi matematis pada kelas yang mendapatkan model pembelajaran ThinkPair-Share (TPS) dengan siswa yang mendapatkan model pembelajaran ekspositori.

Uji ketuntasan belajar digunakan untuk menguji apakah model pembelajaran Think Pair Share (TPS) efektif terhadap kemampuan komunikasi matematis siswa. Uji ketuntasan belajar ada dua macam, yaitu uji ketuntasan individual dan uji ketuntasan klasikal.

Pada ketuntasan individual, siswa dinyatakan tuntas belajar mata pelajaran matematika jika nilai kemampuan komunikasi matematis siswa $\geq 75$. Ketentuan ketuntasan individual mengacu pada nilai KKM yang telah ditetapkan oleh sekolah. Ketentuan ketuntasan klasikal yaitu apabila nilai rata-rata siswa yang tuntas dalam tes kemampuan komunikasi matematis $\geq 75 \%$. Uji ketuntasan belajar individual menggunakan uji t, sedangkan uji ketuntasan belajar klasikal menggunakan uji Z. Hasil uji ketuntasan individual dapat dilihat pada Tabel 8 berikut.

Tabel 8. Hasil Uji Ketuntasan Individual

\begin{tabular}{|c|c|c|c|c|}
\hline Kelas & $\mathrm{N}$ & $t_{\text {hitung }}$ & $t_{\text {tabel }}$ & Keterangan \\
\hline $\mathrm{KE}$ & 24 & 3,616 & 2,81 & $\mathrm{H}_{0}$ ditolak \\
\hline
\end{tabular}
diperoleh $\mathrm{t}_{\text {hitung }}=3,616$ dengan nilai $\mathrm{t}_{\text {tabel }}=2,81$. Taraf signifikansi yang dipakai adalah 5\% $(\alpha=$ $5 \%), \mathrm{db}=\mathrm{n}-1=24-1=23$, sehingga dapat dilihat $t_{\text {hitung }}>t_{\text {tabel }}$, maka $\mathrm{H}_{0}$ ditolak. Jadi dapat disimpulkan bahwa siswa yang memperoleh model pembelajaran TPS mendapat nilai ratarata tes kemampuan komunikasi matematis $>75$. Selain itu, hasil uji ketuntasan klasikal juga dapat dilihat pada Tabel 9 berikut.

Tabel 9. Hasil Uji Ketuntasan Klasikal

\begin{tabular}{ccccc}
\hline Kelas & $\mathrm{N}$ & $\mathrm{Z}_{\text {hitung }}$ & $\mathrm{Z}_{\text {tabel }}$ & Keterangan \\
\hline $\mathrm{KE}$ & 24 & 0.020 & 1.65 & $\mathrm{H}_{0}$ diterima \\
\hline
\end{tabular}

Hasil perhitungan uji ketuntasan klasikal diperoleh $Z_{\text {hitung }}=0.020$ dengan $\alpha=5 \%$, didapatkan $\mathrm{Z}_{\text {tabel }}=\mathrm{Z}_{0.45}=1.65$. Berdasarkan hasil pengujian didapatkan bahwa $Z_{\text {hitung }}>-Z_{\text {tabel }}$ sehingga $\mathrm{H}_{0}$ diterima, dapat disimpulkan bahwa rata-rata siswa yang tuntas KKM berjumlah lebih dari $75 \%$.

Hasil uji ketuntasan individual dan klasikal menunjukkan bahwa lebih dari $75 \%$ 
siswa di kelas eksperimen mendapat nilai ratarata lebih dari 75 pada nilai tes kemampuan komunikasi matematis. Simpulan yang dapat diambil, pembelajaran menggunakan model pembelajaran TPS efektif terhadap kemampuan komunikasi matematis. Hal ini disebabkan nilai tes kemampuan komunikasi matematis siswa telah memenuhi kualifikasi keefektifan yang ditentukan, yaitu memenuhi kriteria ketuntasan individual dengan mendapatkan nilai lebih dari 75 dan memenuhi kriteria ketuntasan klasikal dengan rata-rata siswa yang mendapat nilai lebih dari 75 berjumlah lebih dari $75 \%$.

Penelitian di kelas eksperimen menggunakan model pembelajaran Think-PairShare (TPS). Tahap thinking, merupakan pembelajaran yang diawali dengan pertanyaan yang diberikan oleh guru tentang pelajaran yang sedang diajarkan untuk dipikirkan oleh siswa (Suprijono, 2012:91). Tahap think berlangsung selama 10 menit. Selama proses think, siswa tidak banyak bertanya pada guru tentang kesulitan yang dialaminya. Siswa lebih banyak diam dan fokus untuk menjawab soal pada LKS. Ketika tahap think berlangsung, soal pada LKS siswa masih banyak yang belum dijawab.

Tahap kedua adalah tahap pairing, yaitu siswa berpasang-pasangan untuk mendiskusikan pertanyaan yang tadi mereka pikirkan. Tahap pair dilakukan dua kali dan berlangsung selama 25 menit. Tahap pair yang pertama yaitu tahap berpasangan dan berdiskusi dengan teman sebangku. Ketika proses pair yang pertama ini berlangsung, siswa lebih banyak berdiskusi dengan teman sebangkunya masing-masing. Hal ini sesuai dengan salah satu manfaat TPS yaitu memungkinkan siswa untuk bekerja sendiri dan bekerja sama dengan orang lain (Huda, 2014:206). Tahap pair yang kedua, siswa diharuskan untuk berpasangan dengan pasangan lain. Penentuan kelompok pasangan dilakukan oleh guru. Hal ini bertujuan untuk mempersingkat waktu pembentukan kelompok. Pada tahap pair yang kedua, terdapat banyak ketidakcocokan pasangan satu dengan pasangan yang lain. Siswa cenderung ingin berkelompok dengan teman yang dekat dengan mereka atau berkelompok dengan siswa yang cerdas. Dalam pembelajaran kooperatif, berhasil tidaknya suatu pembelajaran sangat bergantung bagaimana pembelajaran kelompok itu berlangsung. Jika kerjasama antar kelompok berlangsung dengan baik, maka pembelajaran pun akan memperoleh hasil yang baik pula (Fadillah, 2014:11).

Tahap ketiga yaitu tahap sharing, tahap memaparkan hasil diskusi pasangan-pasangan di depan kelas. Pada tahap share, siswa cenderung malu untuk maju ke depan kelas. Setelah diberikan arahan oleh guru untuk maju ke depan kelas dengan berkelompok, siswa kemudian termotivasi untuk maju dan memaparkan hasil diskusi kelompoknya. Tahap share ini sesuai dengan salah satu manfaat TPS yaitu memberikan kesempatan pada siswa untuk menunjukkan partisipasi mereka pada siswa lain (Huda, 2014:206).

Pembelajaran dengan menggunakan model pembelajaran TPS berlangsung selama tiga kali pertemuan dan tes komunikasi matematis dengan satu kali pertemuan. Hasil dari nilai tes kemampuan komunikasi matematis kemudian menjadi data akhir penelitian. Soal tes disusun dengan menyesuaikan indikator komunikasi matematis. Hasil tes yang berupa nilai siswa kemudian dianalisis. Berdasarkan hasil analisis pada data hasil tes kemampuan komunikasi matematis, dapat dilihat bahwa hasil tes untuk kelas yang mendapatkan model pembelajaran TPS mendapatkan rata-rata nilai yang lebih baik yaitu 79.25 dibandingkan siswa yang mendapatkan model pembelajaran ekspositori yaitu 76.11. Variansi lebih besar terdapat pada kelas dengan model pembelajaran TPS. Hal ini berarti kemampuan siswa setelah mendapatkan model pembelajaran TPS lebih bervariasi dibandingkan kelas yang mendapatkan model pembelajaran ekspositori.

Penyebab terjadinya variasi disebabkan pembentukan kelompok pada kelas dengan model pembelajaran TPS. Pembagian kelompok memungkinkan terbentuknya kelompok dengan anggota yang pandai semua, kurang pandai semua, atau gabungan dari siswa yang pandai dan kurang pandai. Hal ini sesuai dengan pengertian diskusi yaitu proses komunikasi antara dua orang atau lebih sehingga terjadi saling berbagi gagasan dan pendapat (Uno, Hamzah dan Nurdin Mohamad, 2015:118). Selain itu, kekurangan dari metode diskusi juga menjadikan variansi lebih besar, diantaranya (1) peserta diskusi mendapat informasi yang terbatas, (2) apabila siswa tidak memahami konsep dasar permasalahan maka diskusi tidak efektif, (3) dapat dikuasai oleh orang-orang yang suka berbicara, (4) alokasi waktu yang sulit karena banyak memakan waktu (Hamdayama, 2014:134).

Pada hasil uji perbedaan rata-rata tes kemampuan komunikasi matematis siswa yang mendapatkan model pembelajaran TPS berbeda secara signifikan dengan hasil tes kemampuan komunikasi matematis siswa yang mendapatkan model pembelajaran ekspositori. Hal ini menunjukkan bahwa model pembelajaran TPS pada materi mengidentifikasi sifat-sifat bangun ruang lebih baik dibandingkan dengan rata-rata 
kemampuan komunikasi matematis siswa yang menggunakan model pembelajaran ekspositori. Hal ini sesuai dengan hasil penelitian Husna, Ikhsan, dan Fatimah (2013:30). yang menyatakan bahwa terjadi peningkatan kemampuan komunikasi matematis siswa yang memperoleh model pembelajaran tipe ThinkPair-Share lebih baik daripada siswa yang memperoleh pembelajaran konvensional yaitu ekspositori, ditinjau dari keseluruhan siswa dan peringkat siswa.

Keefektifan kemampuan komunikasi matematis dapat dilihat dari hasil uji ketuntasan belajar. Pada hasil uji ketuntasan belajar, terdapat dua macam uji yaitu uji ketuntasan individual dan uji ketuntasan klasikal. Pada ketuntasan individual, siswa dinyatakan tuntas belajar mata pelajaran matematika jika nilai kemampuan komunikasi matematis siswa $\geq 75$. Berdasarkan uji ketuntasan individual kemampuan komunikasi matematis kelas eksperimen memperoleh persentase ketuntasan sebesar $79 \%$ dengan 19 siswa tuntas dan 5 siswa tidak tuntas. Hasil uji $t$ menyatakan nilai $t_{\text {hitung }}>t_{\text {tabel }}$, sehingga rata-rata nilai tes kemampuan komunikasi matematis siswa yang memperoleh model pembelajaran TPS mendapatkan nilai $>75$. Pada uji ketuntasan klasikal, siswa dikatakan tuntas secara klasikal apabila nilai rata-rata siswa yang tuntas dalam tes kemampuan komunikasi matematis $\geq 75 \%$. Hasil uji $Z$ didapatkan bahwa $\mathrm{Z}_{\text {hitung }}>\mathrm{Z}_{\text {tabel }}$ sehingga disimpulkan rata-rata

nilai tes kemampuan komunikasi matematis yang memperoleh model pembelajaran TPS mendapatkan nilai $\geq 75$ berjumlah lebih dari 75\%. Sehingga dapat disimpulkan bahwa pembelajaran dengan model pembelajaran TPS dapat memenuhi kualifikasi keefektifan yang ditentukan.

Hasil penelitian didapatkan bukan berdasarkan uji statistik saja, melainkan juga menggunakan hasil observasi. Hasil observasi didapatkan melalui lembar penilaian hasil pengamatan kinerja guru dan pengamatan aktivitas siswa di ranah afektif dan psikomotorik. Penilaian hasil observasi tersebut dilakukan di kelas kontrol dan kelas eksperimen setiap pertemuan pembelajaran berlangsung.

Hasil observasi kinerja guru atau keterampilan mengajar guru dalam pengelolaan pembelajaran matematika model pembelajaran TPS materi mengidentifikasi sifat-sifat bangun ruang mendapatkan hasil total skor pada pertemuan pertama yaitu 94, pertemuan kedua mendapat total skor 92, dan pada pertemuan ketiga mendapat total skor 92 dari jumlah skor total 104. Hal ini berarti pada pertemuan pertama, kedua dan ketiga, kinerja guru mendapatkan persentase berturut-turut dari pertemuan pertama adalah 90,38\%, 88,46\%, dan $88,46 \%$. Meskipun terjadi penurunan aktivitas guru dari pertemuan pertama ke pertemuan kedua, tetapi kriteria aktivitas guru masih menunjukkan kriteria sangat baik. Hampir sama, di kelas kontrol menunjukkan total skor dari hasil observasi keterampilan guru dari pertemuan pertama sampai pertemuan ketiga berturut-turut adalah 93 (89,42\%), 90 (86,53\%), dan 94 $(90,38 \%)$.

Lembar observasi siswa ranah afektif dan psikomotorik dibuat dengan menganut teori ranah afektif dan psikomotik menurut ahli dan disesuaikan dengan model pembelajaran TPS dan kemampuan komunikasi matematis. Pada teori ranah afektif yang digunakan adalah teori dari Krathwohl, Bloom, dan Masia (dalam Solihatin, 2012:13) yang menyatakan bahwa indikator ranah afektif ada 5, yaitu 1) mau menginternalisasikan nilai-nilai (karakterisasi), 2) mau mengorganisasikan nilai-nilai, 3) mau memberikan nilai/ mau memandang bernilai, 4) mau memberikan respon terhadap fenomena tertentu, dan 5) mau menerima fenomena tertentu.

Hasil dari observasi ranah afektif di kelas eksperimen menunjukkan bahwa pada pertemuan pertama, siswa yang mendapatkan kriteria sangat baik berjumlah 23 siswa dan yang mendapatkan kriteria baik hanya 1 siswa. Pada pertemuan kedua di kelas eksperimen, siswa yang mendapat kriteria baik pada ranah afektif berjumlah 3 siswa, sedangkan yang lainnya berkriteria sangat baik yaitu persentase berkisar dari $75 \%$ sampai 95\%. Pada pertemuan ketiga, hampir seluruh siswa mengalami kenaikan skor pada ranah afektif sehingga tidak ada siswa yang berkriteria baik, tetapi semua siswa berkriteria sangat baik. Persentase siswa yang paling rendah adalah $75 \%$, sedangkan yang tertinggi adalah $100 \%$. Hasil observasi ranah afektif di kelas kontrol hampir sama dengan yang ditemukan di kelas eksperimen. Kriteria yang didapatkan siswasiswa kelas kontrol juga berkisar pada kriteria baik dan sangat baik. Pada pertemuan pertama, siswa yang mendapat kriteria baik berjumlah 7 siswa, sedangkan siswa yang mendapat kriteria baik sekali berjumlah 29 siswa. Pada pertemuan ketiga di kelas kontrol, siswa yang mendapat kriteria baik pada ranah afektif bertambah menjadi 12 siswa, sedangkan siswa yang lain mendapat kriteria sangat baik berjumlah 24 siswa.

Lembar observasi ranah psikomotorik yang digunakan menggunakan teori ranah psikomotorik dari Dave (dalam Solihatin, 
2012:18) dengan berdasar 5 taraf kemampuan yaitu naturalisasi, artikulasi, presisi, manipulasi, dan imitasi. Penilaian observasi ranah psikomotorik dilakukan pada pertemuan pertama, kedua, dan ketiga di kedua kelompok sampel.

Pada pertemuan pertama dan kedua di kelas eksperimen, hasil ranah psikomotorik menunjukkan hasil yang sama. Seluruh siswa berkriteria sangat baik. Persentase klasikal siswa di kelas eksperimen pada pertemuan pertama dan kedua sama, yaitu $89,16 \%$. Hasil observasi ranah psikomotorik di kelas eksperimen pada pertemuan ketiga mengalami peningkatan. Hal ini dapat dilihat dari hasil persentase klasikal siswa pada pertemuan ketiga yang mendapat 90,83\% (sangat baik). Hasil observasi ranah psikomotorik di kelas kontrol menunjukkan hasil yang berbeda dengan hasil di kelas eksperimen. Pada pertemuan pertama, kedua, dan ketiga mendapatkan persentase klasikal 86,52\%, 85\%, dan 88,33\%. Meskipun sempat terjadi penurunan, tetapi kriteria ranah psikomotorik di kelas kontrol berkriteria sangat baik.

\section{SIMPULAN}

Simpulan dari penelitian ini yaitu: 1) terdapat perbedaan rata-rata kemampuan komunikasi matematis pada kelas yang mendapat perlakuan model pembelajaran TPS dengan kelas yang mendapat perlakuan model pembelajaran ekspositori, 2) kemampuan komunikasi matematik siswa yang menerima pembelajaran model TPS dapat mencapai kualifikasi keefektifan yang ditentukan. Berdasarkan hasil penelitian diberikan saran bahwa guru sebaiknya lebih memperhatikan siswa yang masih mengalami kesulitan dalam kemampuan komunikasi matematisnya.

\section{UCAPAN TERIMAKASIH}

Penulis mengucapkan terimakasih kepada segenap tim Pengelola Jurnal Anargya yang telah memberikan kesempatan kepada penulis untuk mempublikasikan karya ilmiahnya.

\section{DAFTAR PUSTAKA}

Depdiknas. 2006. Kurikulum Tingkat Satuan Pendidikan. Jakarta: Depdiknas.

Depdiknas. 2007. Kajian Kebijakan Kurikulum Mata Pelajaran Matematika. Jakarta: Pusat Kurikulum Balitbang Depdiknas.

Fadillah, M. 2014. Edutainment Pendidikan Anak Usia Dini: Menciptakan Pembelajaran Menarik, Kreatif, dan Menyenangkan. Jakarta: Kencana.
Hamdayama, Jumanta. 2014. Model dan Metode Pembelajaran Kreatif dan Berkarakter. Bogor: Ghalia Indonesia.

Huda, Miftahul. 2014. Model-model Pengajaran dan Pembelajaran: Isu-isu Metodis dan Paradigmatis. Yogyakarta: Pustaka Pelajar.

Husna, M. Ikhsan, Siti Fatimah. 2013. Peningkatan Kemampuan Pemecahan Masalah dan Komunikasi Matematis Siswa Sekolah Menengah Pertama Melalui Model Pembelajaran Kooperatif Tipe Think Pair Share (TPS). Jurnal Peluang, 1 (2), 90-91.

Khusnaini, Santi Nurul. 2011. Keefektifan Pembelajaran Numbered Head Together (NHT) dan Pembelajaran Think Pair Share (TPS) terhadap Kemampuan Komunikasi Matematik Peserta didik pada Materi Pokok Segiempat. Skripsi. Semarang: Universitas Negeri Semarang.

Lestari, Karunia Eka dan Mokhammad Ridwan Yudhanegara. 2015. Penelitian Pendidikan Matematika. Bandung: PT Refika Aditama.

Solihatin, Etin. 2012. Penilaian Hasil Belajar dengan Teknik Nontes. Yogyakarta: Universitas Sanata Dharma.

Sudjana, Nana. 2011. Dasar-dasar Proses Belajar Mengajar. Bandung: Sinar Baru Algensindo.

Sugiyono. 2012. Metode Penelitian Pendidikan: Pendekatan Kuantitatif, Kualitatif, dan $R n D$. Bandung: Alfabeta.

Sugiyono. 2015. Statistika untuk Penelitian. Bandung: Alfabeta.

Suprijono, Agus. 2012. Cooperative Learning: Teori dan Aplikasi Paikem. Yogyakarta: Pustaka Pelajar.

Susanto, Ahmad. 2013. Teori Belajar dan Pembelajaran di Sekolah Dasar. Jakarta: Paramedia Group.

Trianto. 2011. Model-model Pembelajaran Inovatif Berorientasi Konstruktivistik. Jakarta: Prestas Pustaka.

Ulya, H., dan Rahayu, R. Pembelajaran Treffinger Berbantuan Permainan Tradisional Congklak Untuk Meningkatkan Kemampuan Komunikasi Matematis. Aksioma: Jurnal Program Studi Pendidikan Matematika, 6 (1): 4855.

Uno, Hamzah dan Nurdin Mohamad. 2015. Belajar dengan Pendekatan PAIKEM. Jakarta: Bumi Aksara. 